\title{
GERAKAN MELEK SEJARAH (GAMES): PERAN DIREKTORAT SEJARAH DALAM PENGEMBANGAN PENDIDIKAN SEJARAH
}

\section{Triana}

\author{
GERAKAN MELEK \\ SEJARAH (GEMES): \\ PERAN DIREKTORAT \\ SEJARAH DALAM \\ PENGEMBANGAN \\ PENDIDIKAN SEJARAH
}

DIREKTUR SEJARAH

SUMATERA BARAT, 23 APRIL 2019

\section{Pengantar}

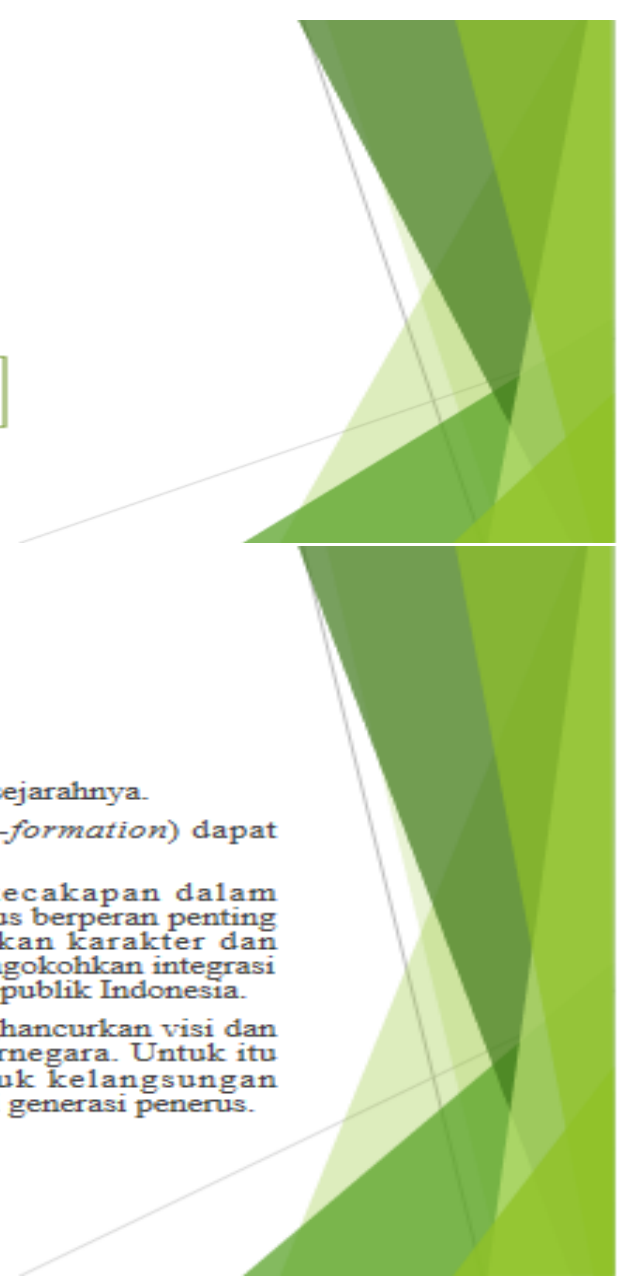

- Karakter suatu bangsa mengakar dalam sejarahnya.

- Terbentuknya sebuah bangsa (nation-formation) dapat dijelaskan melalui sejarah.

- Oleh karena itu, melek sejarah (kecakapan dalam memahami sejarah) bagi generasi penerus berperan penting dalam menumbuhkan dan menguatkan karakter dan identitas bangsa; melek sejarah juga mengokohkan integrasi bangsa dan wilayah Negara Kesatuan Republik Indonesia.

- Sebaliknya, amnesia sejarah akan menghancurkan visi dan kesatuan kehidupan berbangsa dan bernegara. Untuk itu melek sejarah sangat strategis untuk kelangsungan kehidupan berbangsa dan bernegara bagi generasi penerus. 


\section{GEMES (Gerakan Melek Sejarah)}

- Berlandaskan pada pokok pikiran tersebut, Direktorat Sejarah, Direktorat Jenderal Kebudayaan, Kementerian Pendidikan dan Kebudayaan menggagas Gerakan Melek Sejarah (GEMES).

- Gagasan GEMES ini seiring dengan Undang-Undang Republik Indonesia Nomor 5 Tahun 2017 tentang Pemajuan Kebudayaan dan Perpres No. 87 Tahun 2017 tentang Penguatan Pendidikan Karakter.

\section{GEMES (Gerakan Melek Sejarah)}

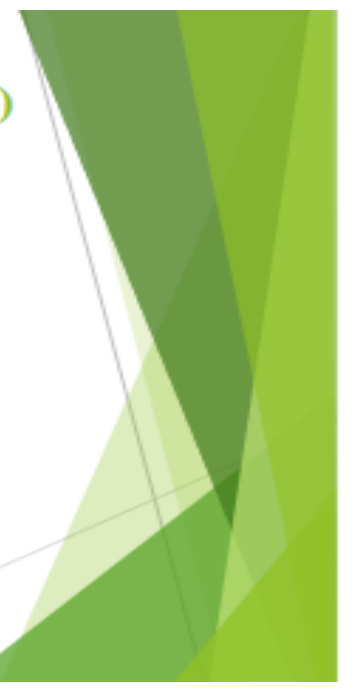

- Gerakan Melek Sejarah ini, goal-nya, akan membangun kesadaran sejarah yang menupakan sumber inspirasi dan aspirasi yang sangat potensial untuk membangkitkan sense of pride (kebanggaan) dan sense of obligation (tanggung jawab dan kewajiban) bagi generasi penerus.

- Substansi kesejarahan yang adalah philosophy teaching by examples (filsafat, nilai-nilai, atau karakter kearifan/kebajikan yang diajarkan melalui contoh-contoh dalam sejarah) dikemas sedemikian rupa dalam aneka program untuk:

1. Melahirkan kebanggaan (sense of pride) sebagai bangsa Indonesia atas karakter, kemulian usaha dan capaian luhur para pendahulu (untuk diteladani).

2. Mendorong tanggung jawab dan kewajiban (sense of obligation) terhadap amanat sejarah tersebut yang harus diteruskan oleh generasi muda kini untuk memajukan bangsa ini.

11

Sejarah dalam

UU No. $5 / 2017$
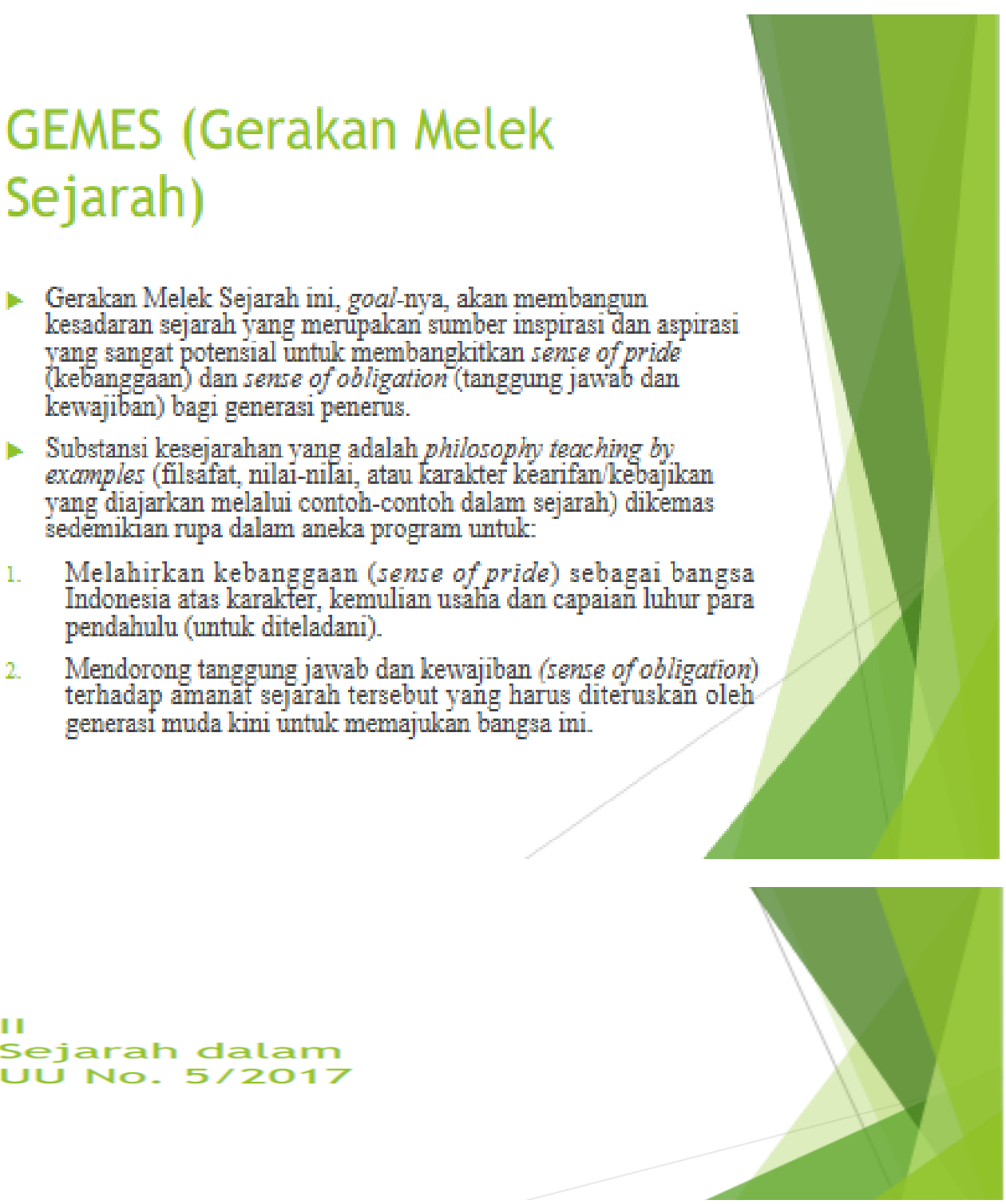


\section{Garis Besar UU No. 5/2017}

(] UU No. 5/2017 tentang Pemajuan Kebudayaan merupakan penerjemahan dari amanat Pasal 32 ayat (1) UUD 1945: "Negara memajukan kebudayaan nasional Indonesia di tengah peradaban dunia dengan menjamin kebebasan masyarakat dalam memelihara dan mengembangkan nilai-nilai budayanya".

1] Pasal 1 UU No. 5/2017: "Pemajuan Kebudayaan adalah upaya meningkatkan ketahanan budaya dan kontribusi budaya Indonesia di tengah peradaban dunia melalui Pelindungan, Pengembangan, Pemanfaatan, dan Pembinaan Kebudayaan."

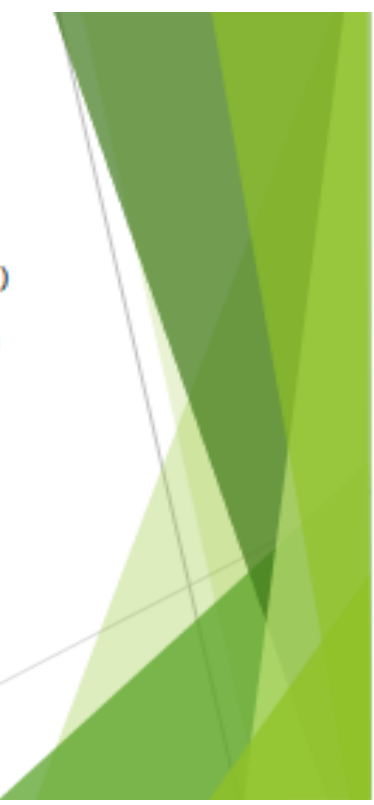

\section{Letak Sejarah dalam Taksonomi Objek Pemajuan Kebudayaan}

( Apa yang dimajukan? 10 Objek Pemajuan Kebudayaan: (1) tradisi lisan, (2) manuskrip, (3) adat istiadat, (4) ritus, (5) pengetahuan tradisional, (6) teknologi tradisional, (7) seni, (8) bahasa, (9) permainan rakyat dan (10) olahraga tradisional.

D Di mana letak sejarah?

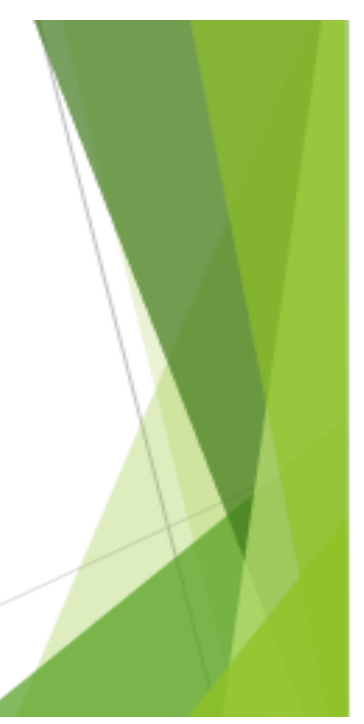




\section{Sejarah sebagai Dimensi Objek Kebudayaan}

- Sejarah bukan objek kebudayaan, tapi dimensi dari semua objek kebudayaan:

[ Semua praktik yang menghasilkan $10 \mathrm{OPK}$ diciptakan lewat proses sejarah

(1) Semua nilai yang terkandung dalam 10 OPK diciptakan lewat proses sejarah

口 Karena sejarah adalah dimensi objek kebudayaan, maka pemajuan atas objek itu hanya bisa dilakukan dengan dukungan kajian sejarah.

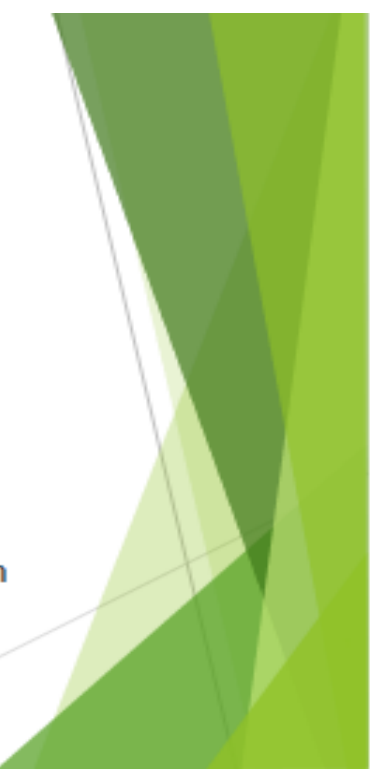

\section{Sejarah sebagai Metode Pemajuan Kebudayaan}

- Sejarah bukan objek kebudayaan, tapi metode untuk memajukan semua objek kebudayaan:

1] Tidak ada pelindungan tanpa pendataan dan pengarsipan (sejarah)

(1) Tidak ada pengembangan tanpa pengkajian (sejarah)

(1) Tidak ada pemanfaatan tanpa wawasan tentang kebudayaan nasional (sejarah)

( Tidak ada pembinaan tanpa internalisasi nilai-nilai (sejarah)
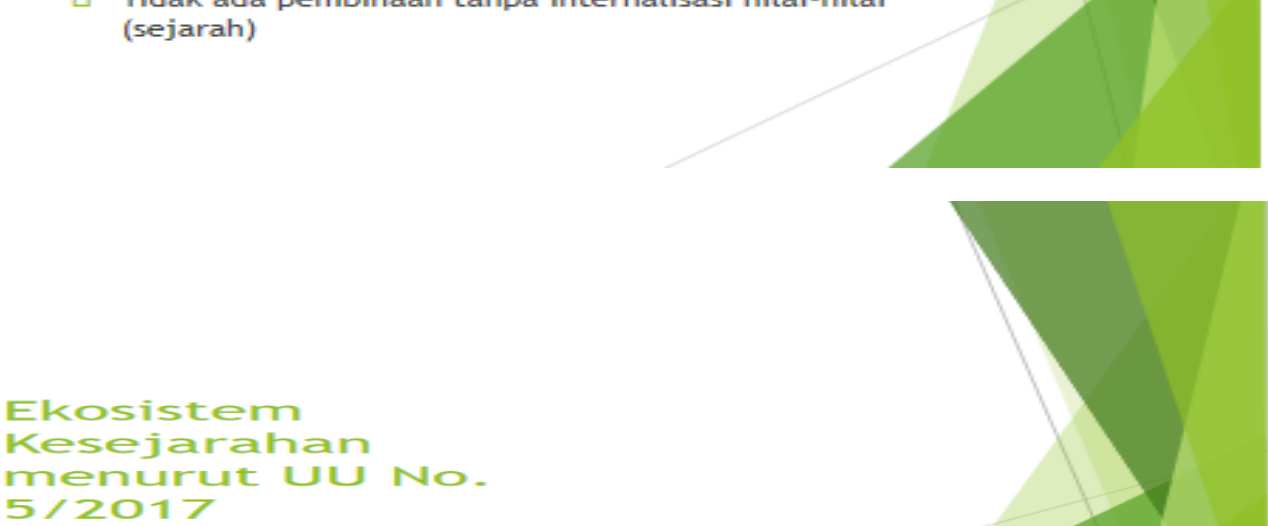


\section{Ekosistem Pemajuan Kebudayaan}

(] Pasal 43 dan 44 UU No. 5 / 2017: dalam memajukan kebudayaan Pemerintah Pusat dan Daerah bertugas "menghidupkan dan menjaga ekosistem kebudayaan yang berkelanjutan".

(1) Ekosistem kebudayaan adalah tata interaksi yang saling menunjang antara pelindungan, pengembangan, pemanfaatan dan pembinaan kebudayaan.

(1) Agar tata interaksi itu saling menunjang dan berkelanjutan, maka harus ada produksi dan reproduksi:

[] Momen produksi: pelindungan \& pengembangan

(1) Momen reproduksi: pemanfaatan \& pembinaan
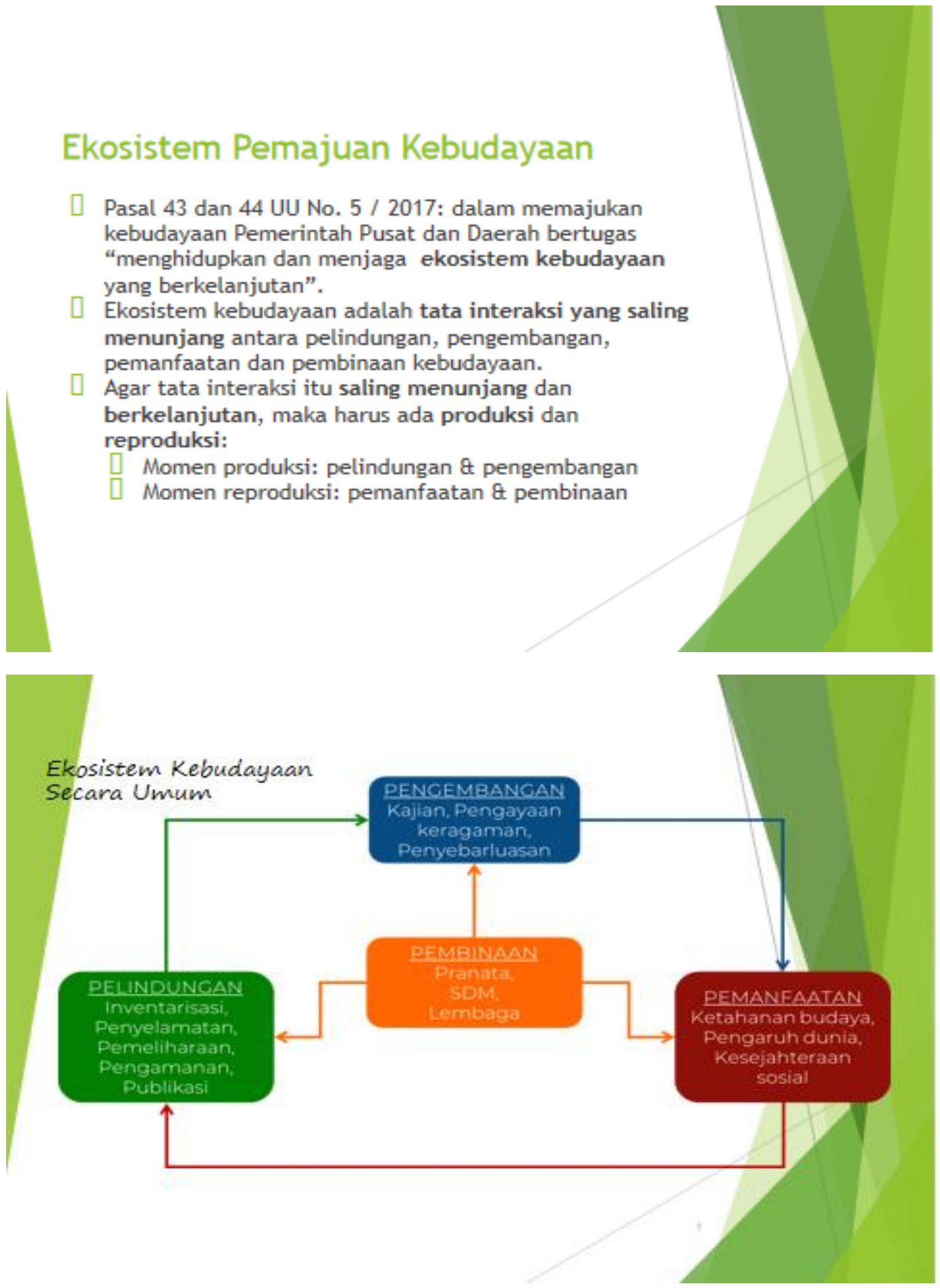


\section{Ekosistem Kesejarahan}

- Seperti halnya ekosistem kebudayaan secara umum, ekosistem kesejarahan pun agar berkesinambungan mesti ditopang oleh relasi siklis antara produksi dan reproduksi:

1 Produksi pengetahuan sejarah

(pengumpulan dan pengkajian sumber sejarah)

D Distribusi pengetahuan sejarah

(digitalisasi dan diseminasi sumber dan kajian sejarah)

(1) Konsumsi pengetahuan sejarah

(internalisasi nilai sejarah, peningkatan apresiasi publik)

1 Ketiganya mesti dipandang sebagai subsistem dari ekosistem kesejarahan. Artinya, masing-masing tidak bisa dan tidak seharusnya berdiri sendirisendiri.

Ekosistem Kesejarahan Secara Umum

\section{Sumber}

Database

Sejarah

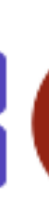

Produksi

Pengetahuan Sejarah
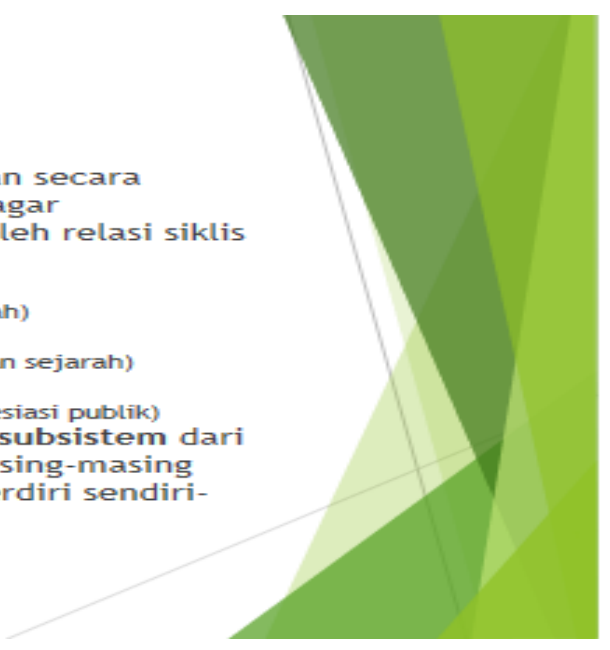

\section{Apresiasi \\ Anuralu.}

Internalisasi

Nilai Sejarah

Peningkatan

Kermawrasan

Peningkatan

Apresiasi

Publik thd

Sejarah

Histariografis

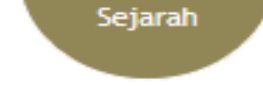

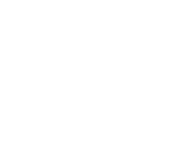

\section{Konsolidasi}

Metode

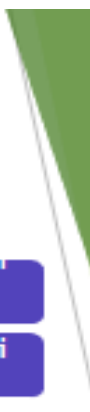

vecarain

Kanal
Diseminasi

Pengetahuan

Sejarah

ingeimrassal

Konten

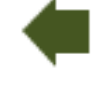

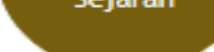

Meinyevalan

Konten 


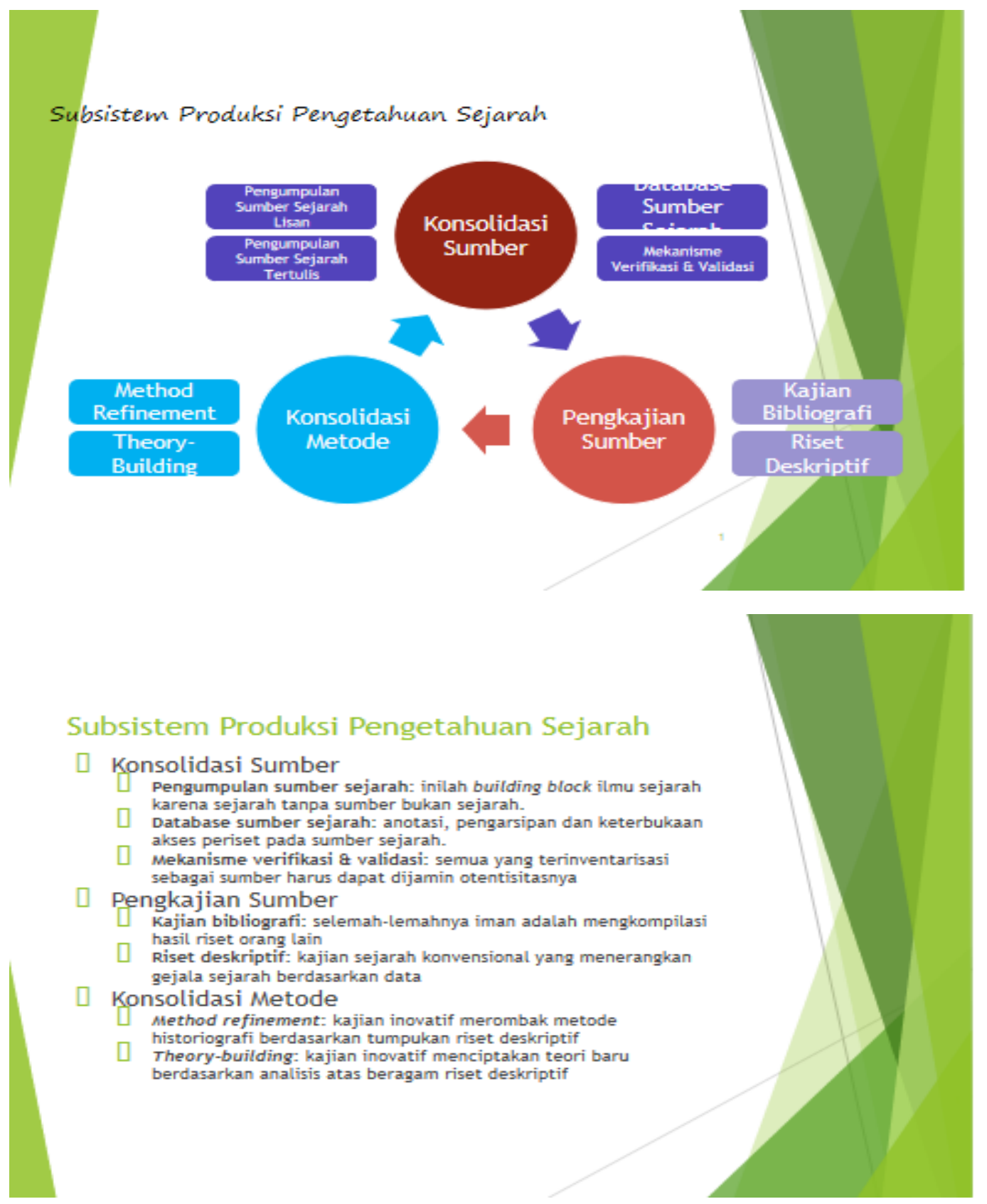

75 | Seminar Nasional Sejarah ke 4 Jurusan Pendidikan Sejarah Universitas Negeri Padang 
Subsistem Diseminasi Pengetahuan Sejarah

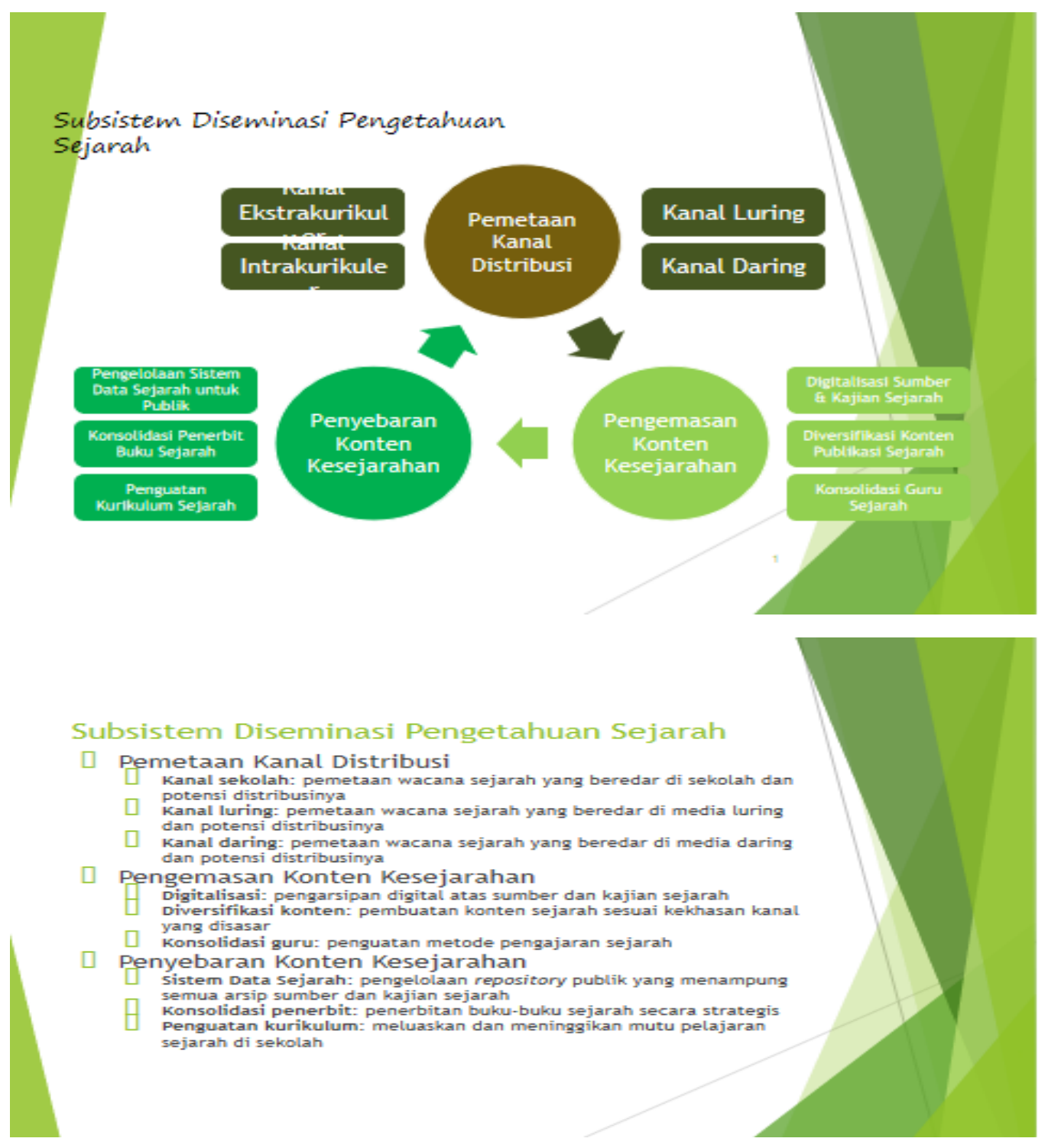


Subsistem Peningkatan Apresiasi Publik terhadap Sejarah

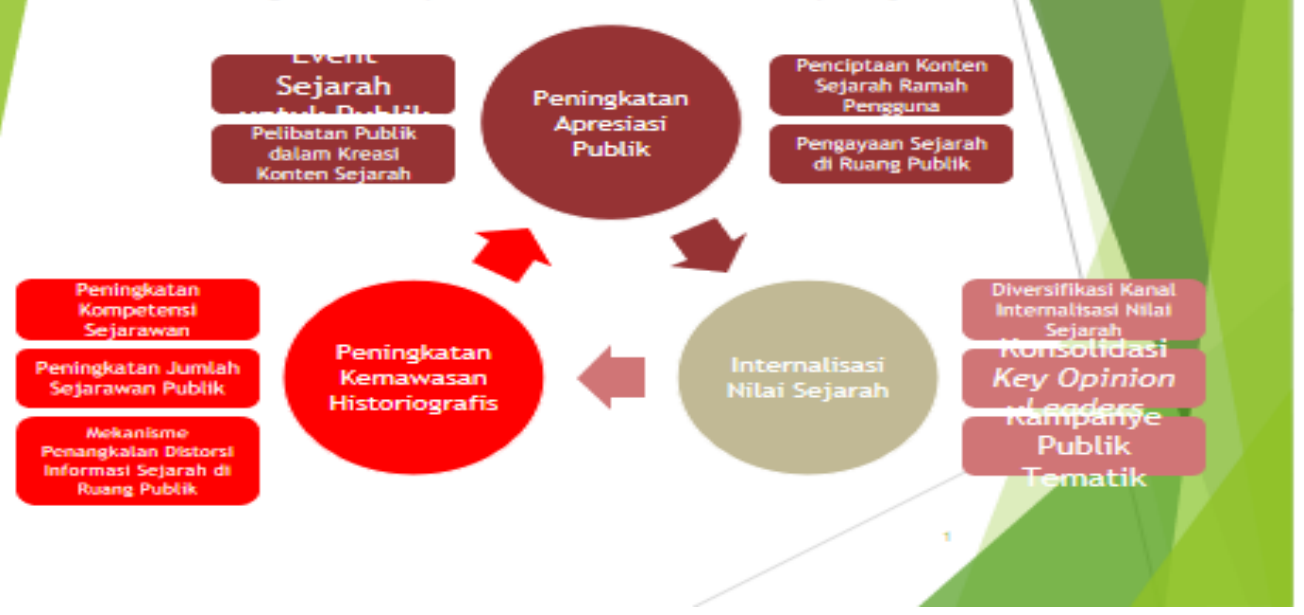

Subsistem Peningkatan Apresiasi Publik terhadap Sejarah

( Peningkatan Apresiasi Publik

Event sejarah untuk publik: festival atau kegiatan publik yang meningkatkan penghargaan masyarakat atas sejarah

1 Pelibatan publik: mengikutsertakan publik dalam kreasi konten

sejarah yang akan dinikmati publik

Pengayaan sejarah di ruang publik: intervensi di ruang publik untuk meningkatkan kesadaran sejarah masyarakat

( Internalisasi Nilai Sejarah

Diversifikasi kanal: membentuk kanal-kanal penanaman nilai dengan desain konten yang kontekstual (Sekolah, komunitas, pesantren, dan TNI)-

Konsolidasi key opinion leaders: memanfaatkan influencers sebagai pelaku internalisasi nilai sejarah di masyarakat

Kampanye publik tematik: membangun strategi kampanye nilai sejarah secara konsisten dalam jangka waktu tertentu dengan konten yang makin berbobot seiring waktu (harus lebih berbobot daripada kegiatan peningkatan apresiasi publik)

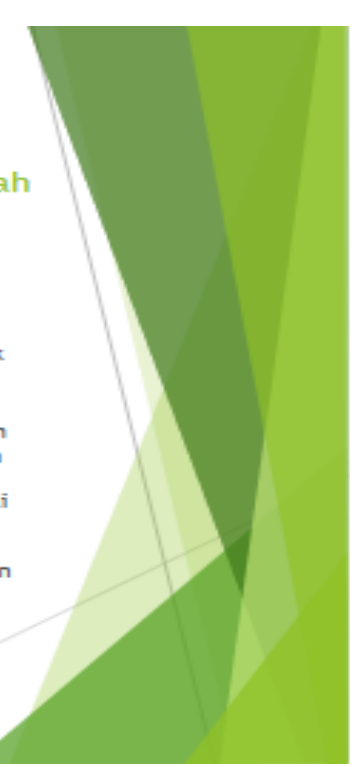


Subsistem Peningkatan Apresiasi Publik terhadap Sejarah

(1) Peningkatan Kemawasan Historiografis

Peningkatan kompetensi sejarawan: memperkaya wawasan dan metode para sejarawan profesional dan para pengajar sejarah Peningkatan jumlah sejarawan publik: melipatgandakan jumlah sejarawan organik yang tumbuh dari masyarakat setempat dan menulis kajian sejarah lokal yang dapat dipertanggung-jawabkan secara metodologis

1] Mekanisme penangkalan disinformasi sejarah di ruang publik: membangun sistem yang memungkinkan masyarakat yang telah terpapar pada peningkatan apresiasi sejarah dan internalisasi nilai terpapar pada peningkatan apresiasi sejarah dan internalisasi nilai sejarah untuk:

- Mengidentifikasi distorsi informasi $/$ hoax kesejarahan yang beredar di masyarakat

2. Mampu memberikan narasi sejarah tandingan atas hoax tersebut dengan memanfaatkan kemawasan atas disiplin historiografis (kritik sumber dan wawasan sejarah kebangsaan)

\section{PENGERTIAN MELEK}

\section{SEJARAH}

- Apa itu melek gejarah?

- Melek gejarah adalah tujuan dari belajar sejarah.

- Orang yang melek sejarah adalah orang yang berpengetahuan luas tentang masa lampau. Pengetahuan yang dikualifikasikan sebagai melek sejarah adalah pengetahuan yang koheren, konseptual, dan penuh makna tentang masa lampau yang berdasarkan pada penggunaan bukti sejarah yang kritis.

- Melek gejarah juga dapat didefinisikan dalam pengertian tradisional yaitu orang yang mampu menulis dan membaca. Dalam hal ini tujuan melek gejarah adalah memampukan siswa dan masyarakat untuk membaca teks gejarah dengan kritis, menulis dengan penuh pengertian dan permenungan, dan terlibat dalam diskusi-diskusi yang penuh makna mengenai masa lampau.

- Dalam pengertian ini juga, melek sejarah berarti pemahaman yang mendalam tentang peristiwa-peristiwa gejarah dan proses-prosesnya melalui keterlibatan aktif dengan teks-teks sejarah.
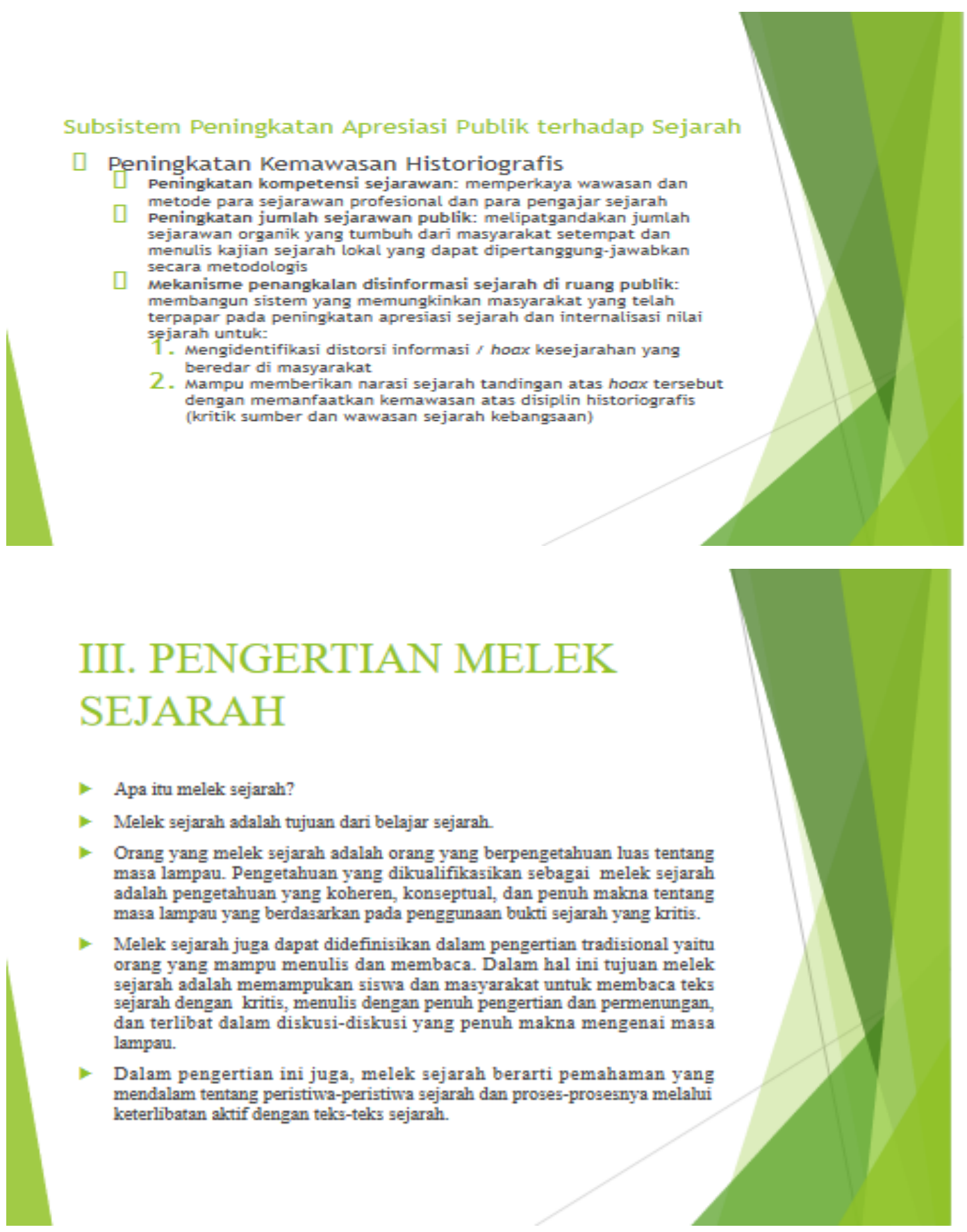


\section{PENGERTIAN MELEK SEJARAH}

Orang yang melek sejarah musti mampu berpikir historis. Untuk berpikir historis orang harus mampu:

1. Menentukan suatu peristiwa adalah suatu peristiwa yang penting.

2. Menggunakan bukti sumber primer.

3. Mengidentifikasikan kesinambungan dan perubahan

4. Menganalisis sebab dan akibat.

5. Mempunyai perspektif historis.

6. Memahami dimensi etis dalam sejarah.

\section{PENGERTIAN MELEK SEJARAH}

- Orang yang melek sejarah mengerti bahwva buku sejarah atau film dokumenter di televisi itu adalah tafsiran seseorang dan bukanlah keseluruhan kebenaran mengenai masa lampau.

- Masyarakat yang melek sejarah dapat menilai keabsahan klaim-klaim dalam peristiwa-peristiwa sejarah Indonesia. Mereka penuh pemahaman dalam menangani perdebatan ini. Mereka dapat mempertanyakan sumber-sumber sejarah. Mereka mengerti nilai catatan kaki. Singkatnya, mereka dapat mendeteksi perbedaanperbedaan antara penggunaan dan penyalahgunaan sejarah.

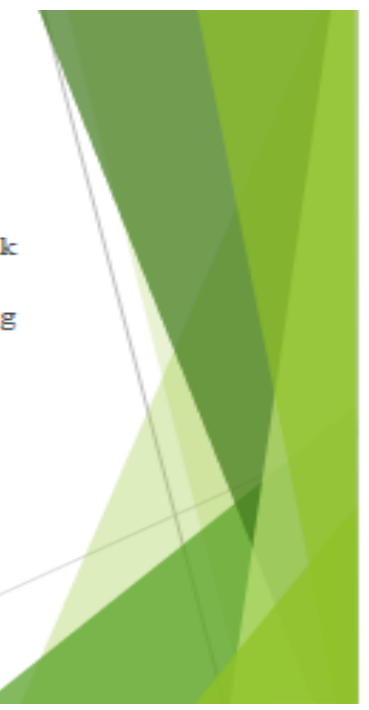

\section{PENGERTIAN MELEK SEJARAH}

Dengan demikian,

Melek sejarah Indonesia adalah kecakapan dalam memahami sejarah Indonesia untuk memperkuat karakter bangsa.
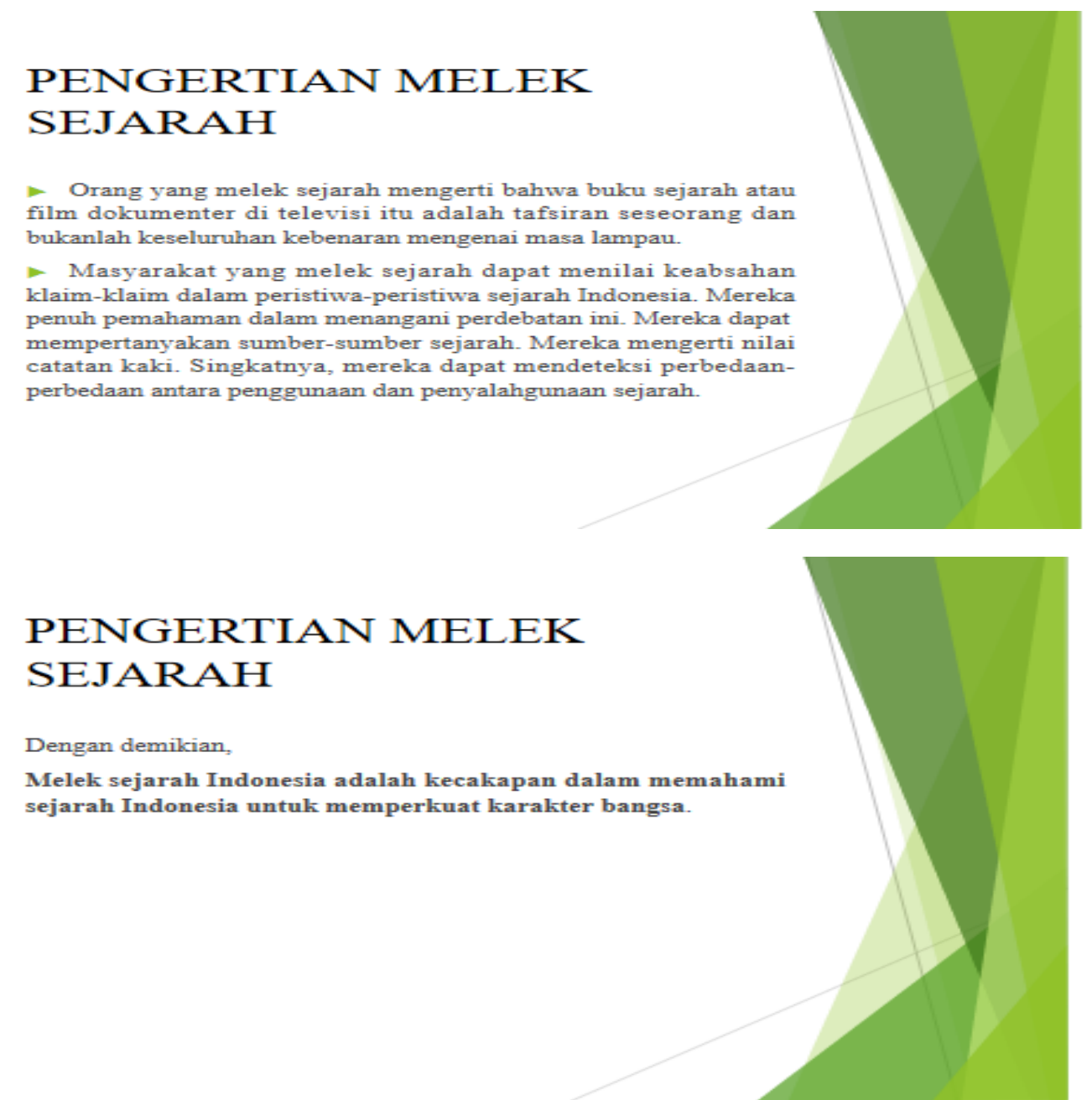
IV. KERA NGKA UNTUK MELEK

$\begin{array}{lllllll}\mathbf{S} & \mathbf{E} & \mathbf{J} & \mathbf{A} & \mathbf{R} & \mathbf{A} & \mathbf{H}\end{array}$

Kerangka untuk melek sejarah:

Mesti dikaitkan dengan peranan sejarah dalam kurikulum sekolah dan kehidupan bangsa, yaitu memperkuat identitas dan karakter bangsa.

Melek sejarah menyediakan dasar pemikiran untuk pendidikan sejarah yang didasarkan pada disiplin ilmu sejarah itu sendiri. Sejarah adalah satu-satunya disiplin atau mata pelajaran di sekolah yang mengurusi bagaimana masyarakat itu berubah.

Pedagogi melek sejarah harus membantu siswa dan masyarakat mengerti bahwa masa lampau mempunyai relevansi untuk masa sekarang.

\section{PROGRAM MELEK SEJARAH}
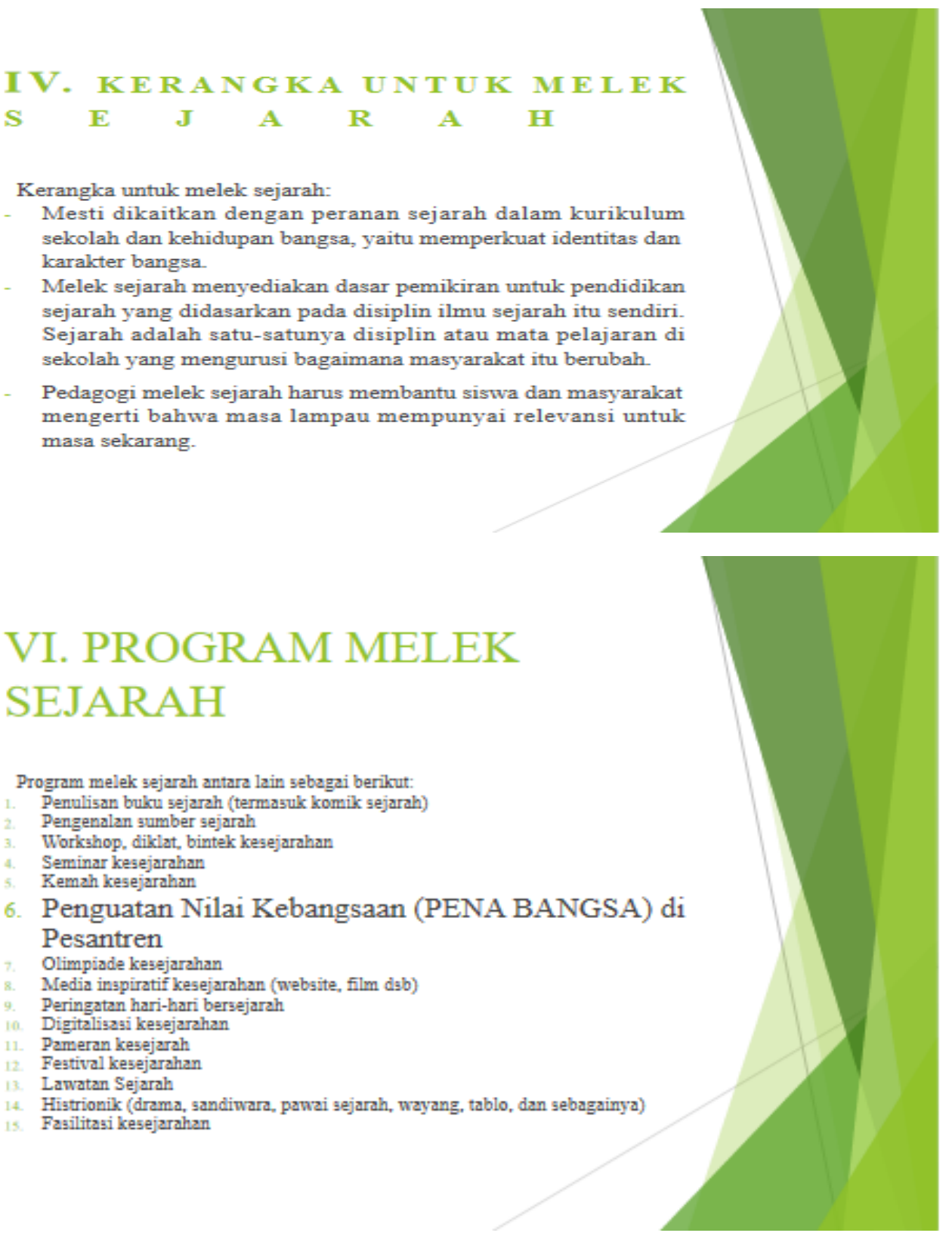


\section{PROGRAM MELEK SEJARAH}

- Ragam kegiatan Gerakan Melek Sejarah (GEMES) ini sudah mencakup arus sistemik dari produksi pengetahuan sejarah (pengumpulan sumber sejarah dan penulisan sejarah), diseminasi pengetahuan sejarah (digitalisasi dan diseminasi kajian sejarah), sampai konsumsi pengetahuan sejarah (pemanfaatan nilai sejarah).

- Aspek arus sistemik dari GEMES tersebut berpengaruh dalam pengembangan pendidikan sejarah terutama dalam merumuskan tema-tema baru dan teknik-teknik penyajian materi sejarah yang menarik (Masyarakat/siswa sebagai subyek sejarah).

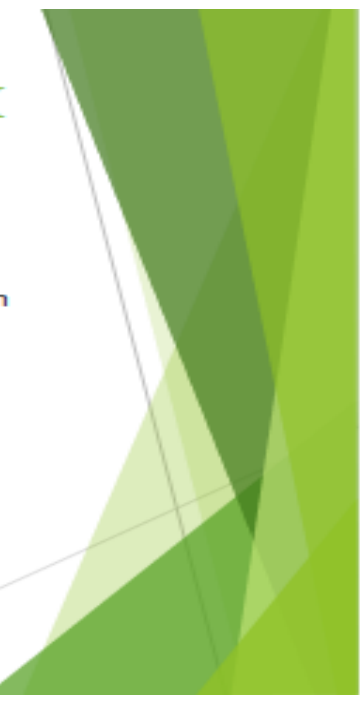


Direktorat Sejarah, MSI, dan PPSI (Perkumpulan

Prodi-Prodi Sejarah Seluruh Indonesia):

Kemitraan dalam Pengembangan Pendidikan Sejarah

- Dalam rangka mengevaluasi pelaksaan pendidikan

kesejarahan di Indonesia dan upaya untuk memperbaiki dan pengembangkan pendidikan kesejarahan di Indonesia pada masa depan, Direktorat Sejarah, Direktorat Jenderal

Kebudayaan, Kementrian Pendidikan dan Kebudayaan Republik Indonesia, bekerjasama dengan MSI, PPSI dan Departemen Sejarah Fakultas IImu Budaya Universitas Gadjah Mada telah menyelenggarakan Seminar Sejarah Nasional dengan tema "Paradigma dan Arah Baru

Pendidikan Kesejarahan di Indonesia", pada tanggal 3-4 Desember 2018 di Fakultas Ilmu Budaya Universitas Gadjah Mada Yogyakarta.

- Seminar menghadirkan 125 pemakalah dan 6 pembicara kunci dari seluruh Indonesia. Seminar menyimpulkan bahwa pendidikan kesejarahan memiliki arti yang sangat penting untuk menumbuhkembangkan kesadaran kebangsaan, nasionalisme, cinta tanah air dan kebhinekaan di Indonesia.

\section{Hasil Rekomendasi}

- Butir-butir rekomendasi dalam seminar tersebut antara lain adalah:

- Guru sejarah menjadi figur sentral yang akan menjadi subyek penting dalam pendidikan kesejarahan. Oleh karena itu, peningkatan kualitas guru sejarah harus menjadi prioritas penting dalam pendidikan kesejarahan kini dan masa depan. Peningkatan kualitas guru itu meliputi peningkatan kemampuan penguasaan substansi sejarah, metode, dan metodologi pembelajaran sejarah.

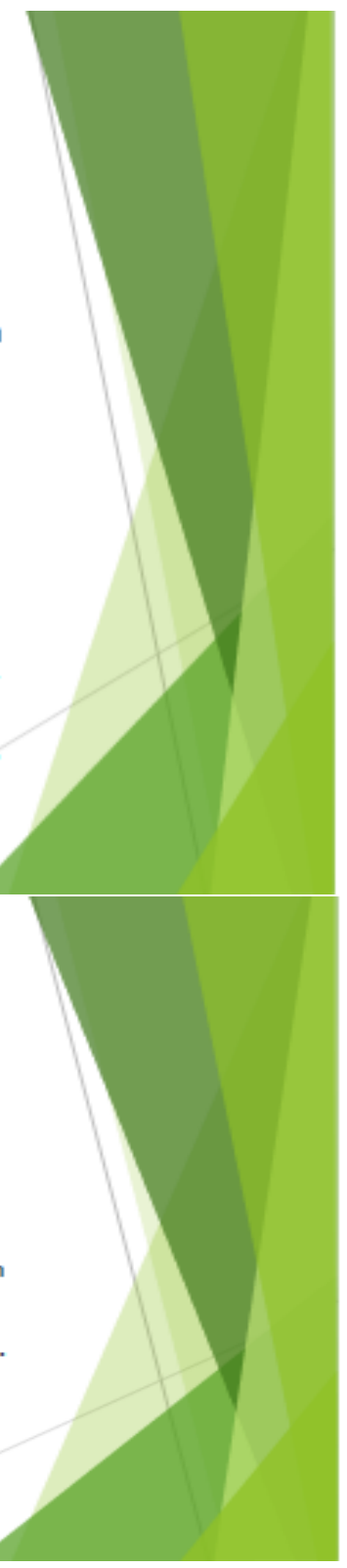




\section{Hasil Rekomendasi}

- Aspek tekonologi informasi. Jadi, pendidikan kesejarahan harus mekaligus menghadirkan sejarah dalam berbagai bentuk;

- Aspek kurikulum, yaitu Kurikulum Pendidikan Sejarah di sekolah menengah yang diterapkan saat ini memerlukan peninjauan ulang disesuaikan dengan perkembangan-perkermbangan dan perubahan perubahan baru dalam pemahaman kesejarahan masyarakat yan dalam substansi pembelajarannya dari sejarah politik ke sejarah sosial, budays pembetajarannya dari sejarah potitik ke sejarah sosial, budaya dan sejaran intelektuat pemikiran. Hat ini untuk kelompok-kelompok sosial marginal/nonelit dan juga untuk menampilkan tokoh-tokoh sejarah baru di bidang sosial, permikiran/intelektualitas dan kebudayaan; aspek sumber belajar, paradigma baru harus segera dilakukan dengan mengikutsertakan para sejarawan akademik bereputasi yang diwadahi oleh beberapa Perkumpulan Prodi-Prodi Sejarah Seluruh Indonesia (PPSI).

\section{Direktorat Sejarah dan Asosiasi Guru Sejarah Indonesia (AGSI): Kemitraan untuk mengembangkan Pendidikan Sejarah}

- Direktorat Sejarah bersama Asosiasi Guru Sejarah Indonesia mengadakan Musyawarah Kerja Nasional pada tanggal 22 Februari 2019 di LPMP Yogyakarta.

- Rekomendasi dari pertemuan ini antara lain adalah:

- Pemerintah memberikan kesempatan dan fasilitasi yang seluas-luasnya kepada guru sejarah dan peserta didik untuk memanfaatkan secara mudah dan berdaya guna seluruh sumber sejarah seperti museum, perpustakaan,empat-tempat bersejarah agar proses pembelajaran sejarah diruang kelas dapat berjalan optimal untuk mencapai tujuan pembelajaran sejarah.

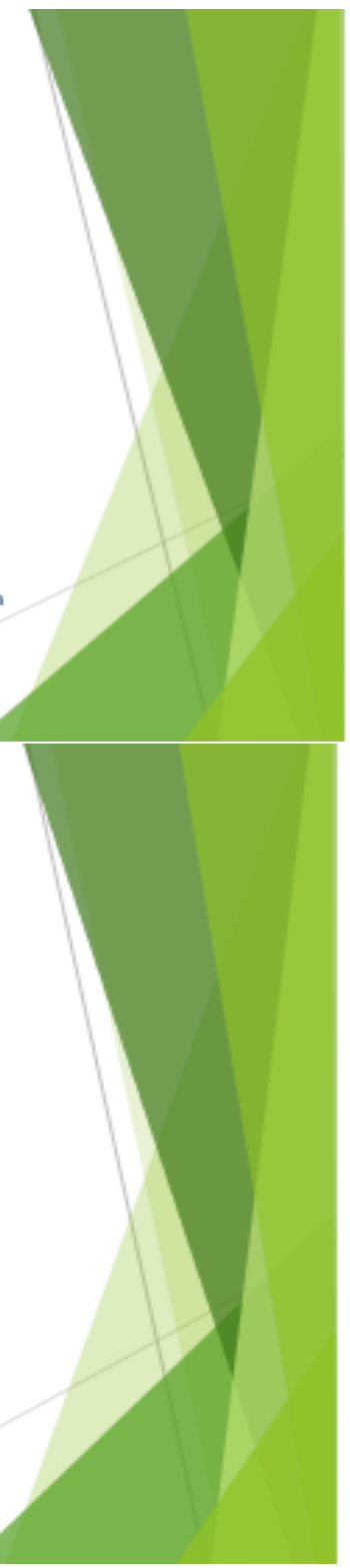




\section{Lanjutan..}

- Pemerintah memberikan ruang seluas-luasnya kepada Asosiasi Guru Sejarah Indonesia dan Musyawarah Guru Mata Pelajaran Sejarah dalam merumuskan dan merealisasikan kebijakan-kebijakannya, terutama yang terkait dengan program untuk memajukan profesionalitas dan kompetensi guru sejarah agar terus berkembang dan besama pemerintah membangun masa depan Indonesia yang lebih baik.

\section{Buku Grafis Sejarah}
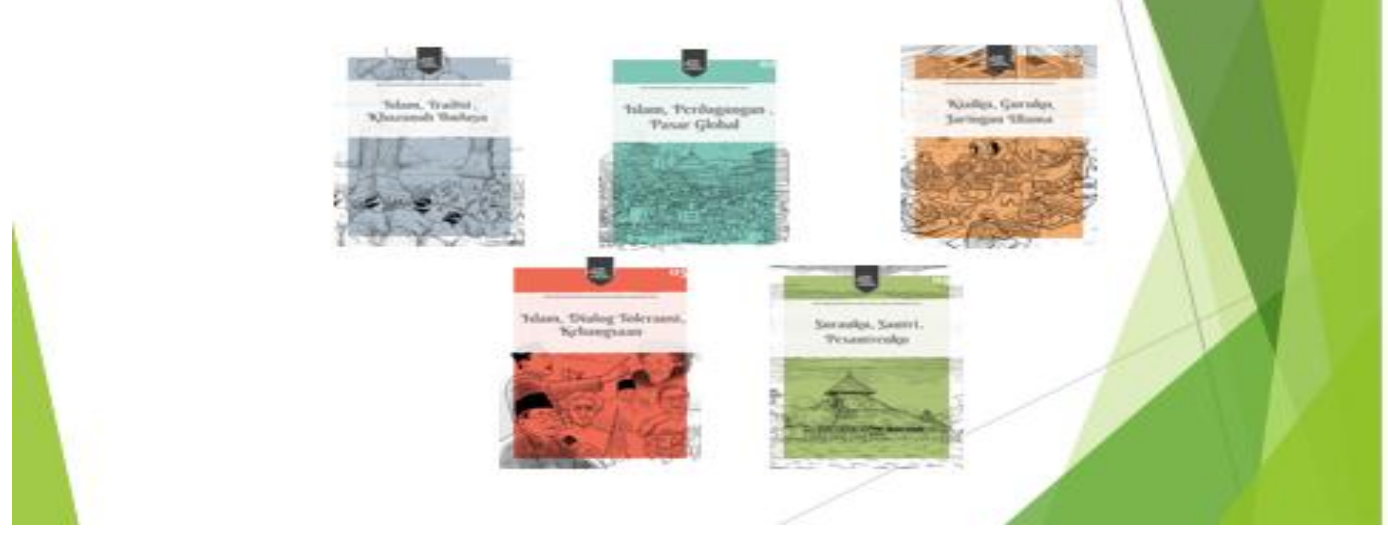


\section{Buku Sejarah}
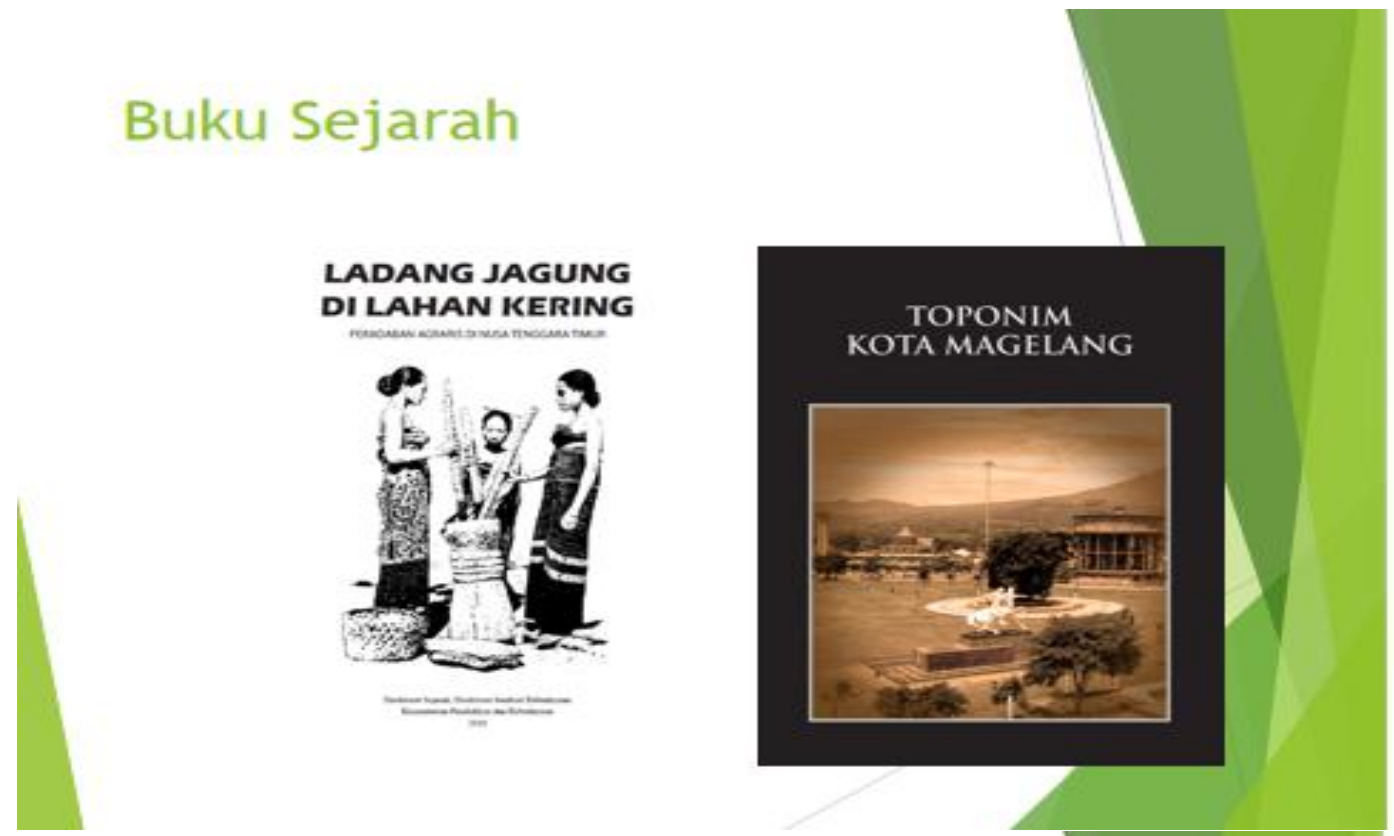

\section{Buku Sejarah}
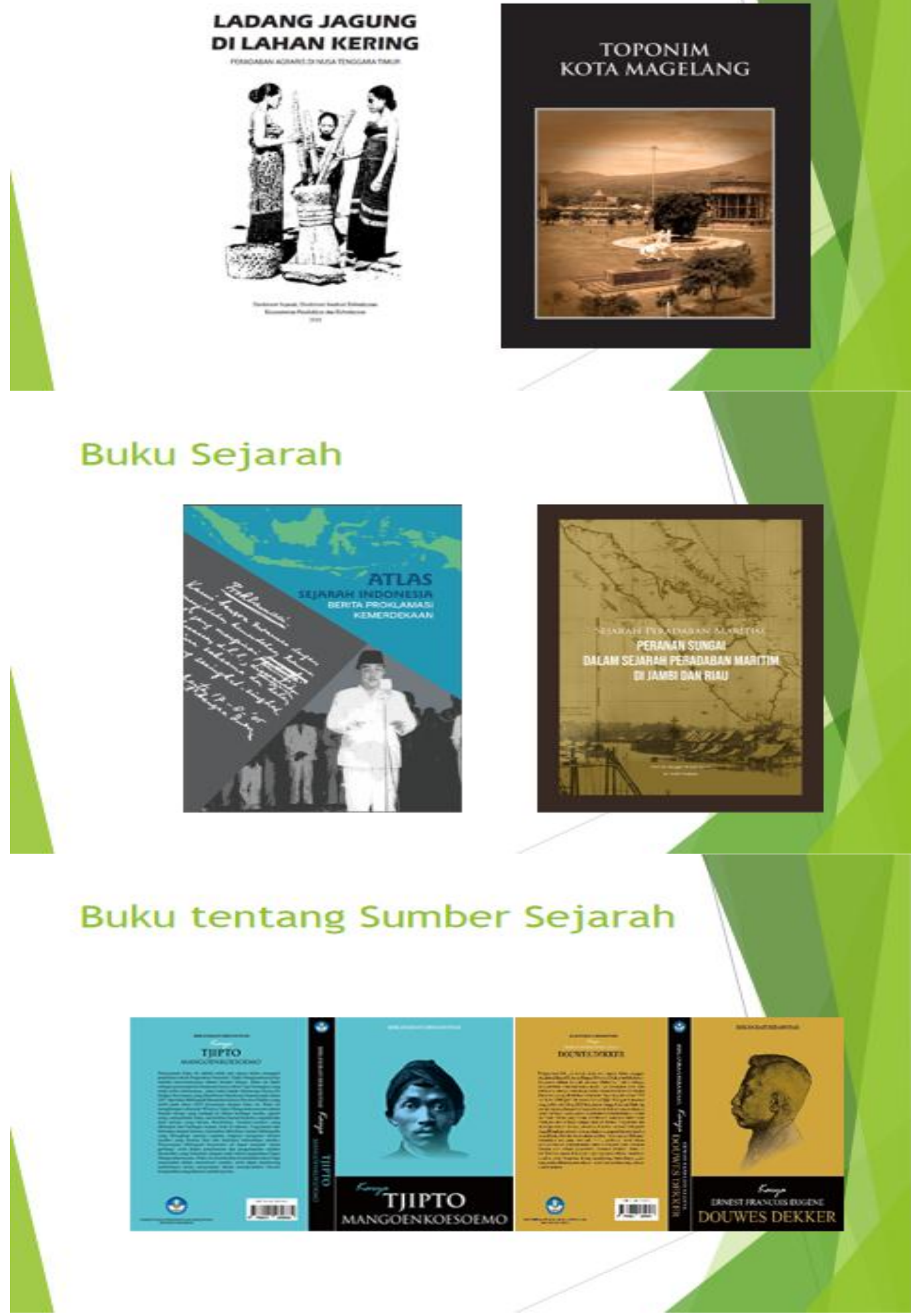

85 | Seminar Nasional Sejarah ke 4 Jurusan Pendidikan Sejarah Universitas Negeri Padang 


\section{Buku tentang Sumber Sejarah}
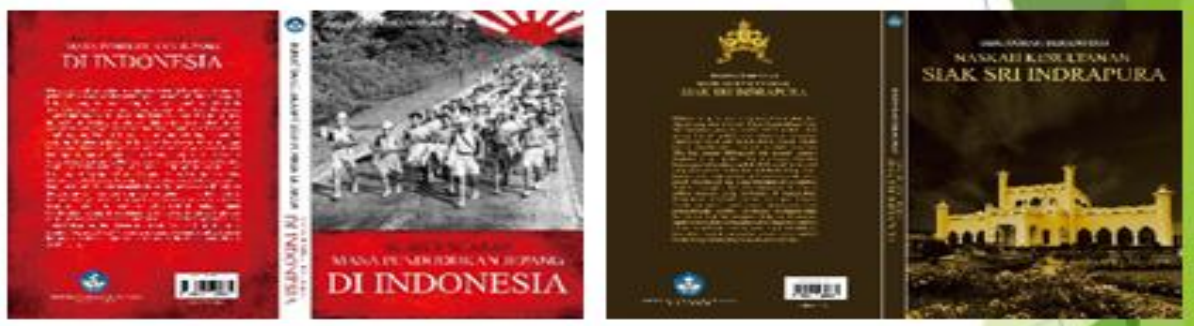

Olimpiade Sejarah Nasional:

Lomba Debat Sejarah

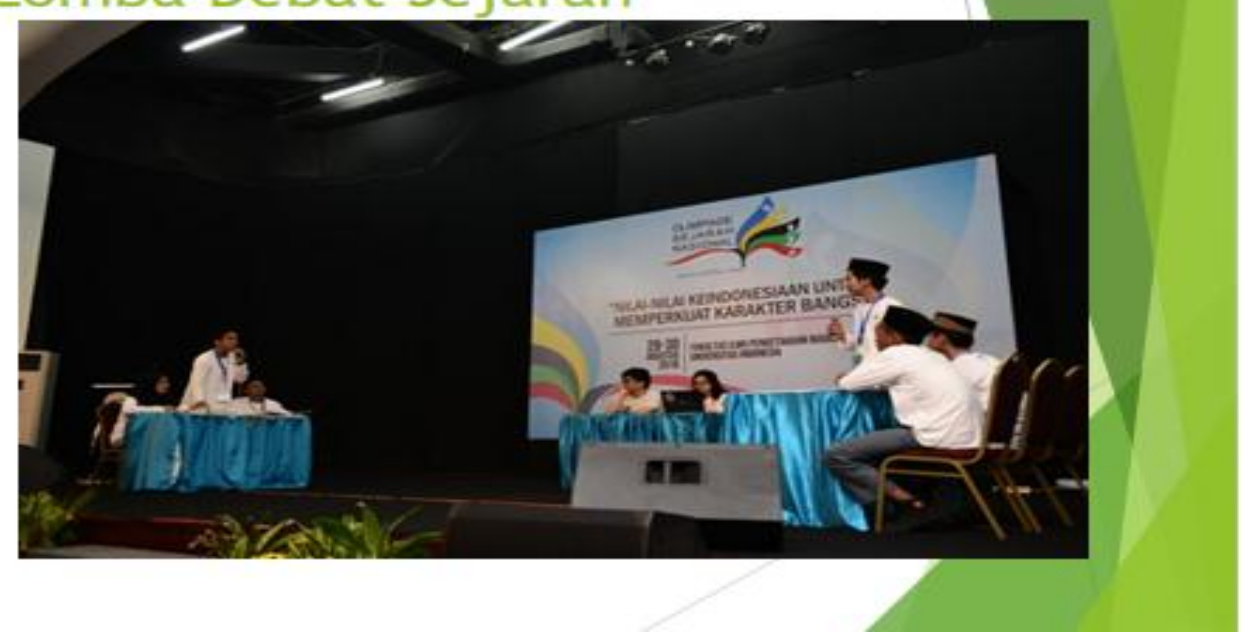


Olimpiade Sejarah Nasional:

Lomba Tutur Sejarah
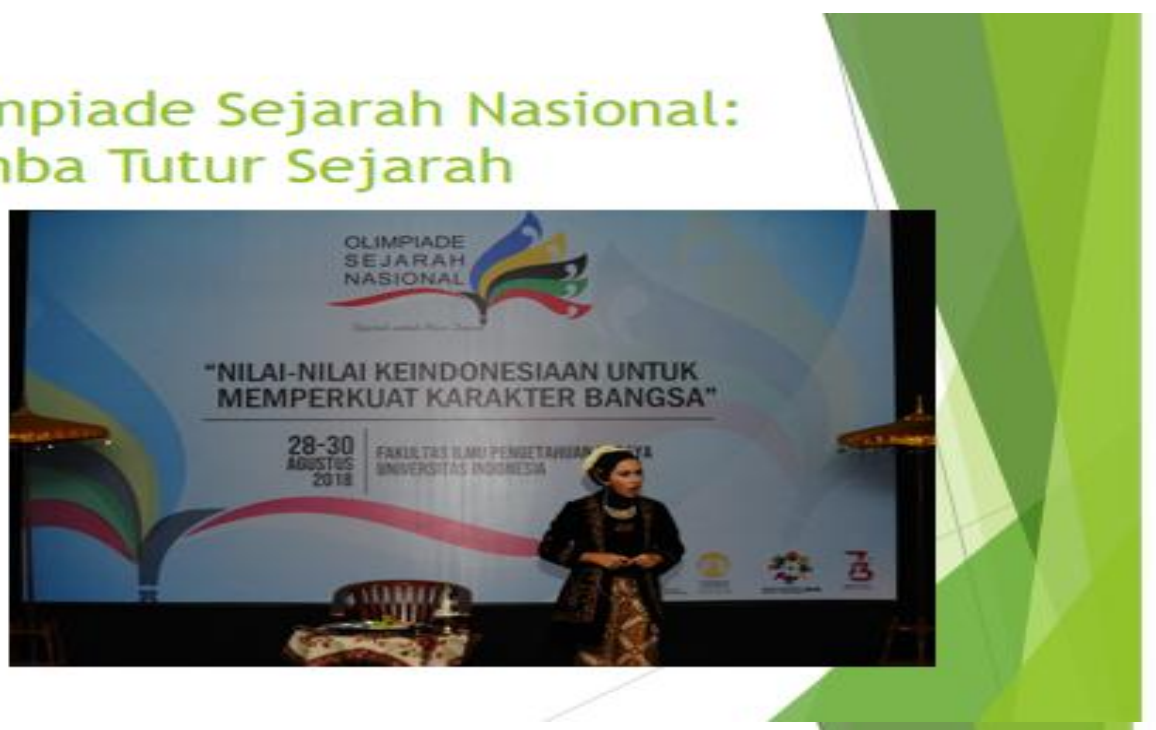

Olimpiade Sejarah Nasional:

Lomba Komik Sejarah

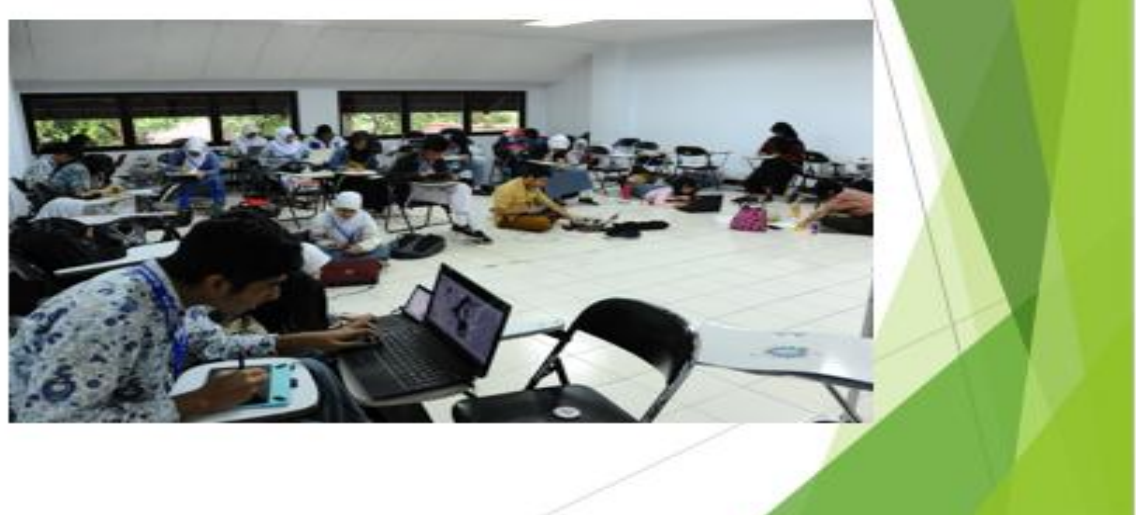


Peserta Lawatan Sejarah Nasional (LASENAS) mengunjungi Makam Laksamana Keumalahayati di Krueng

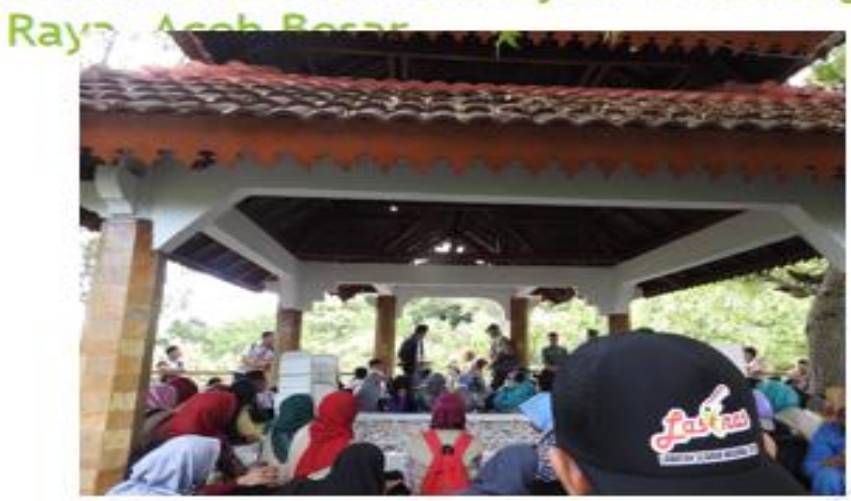

Pameran Kesejarahan

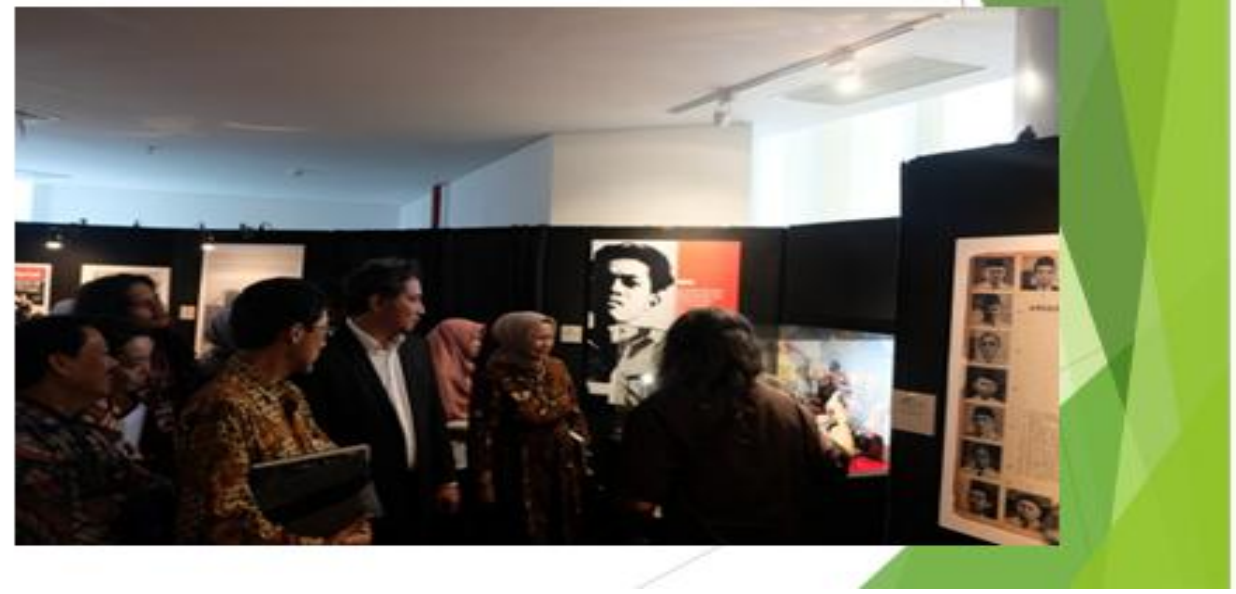




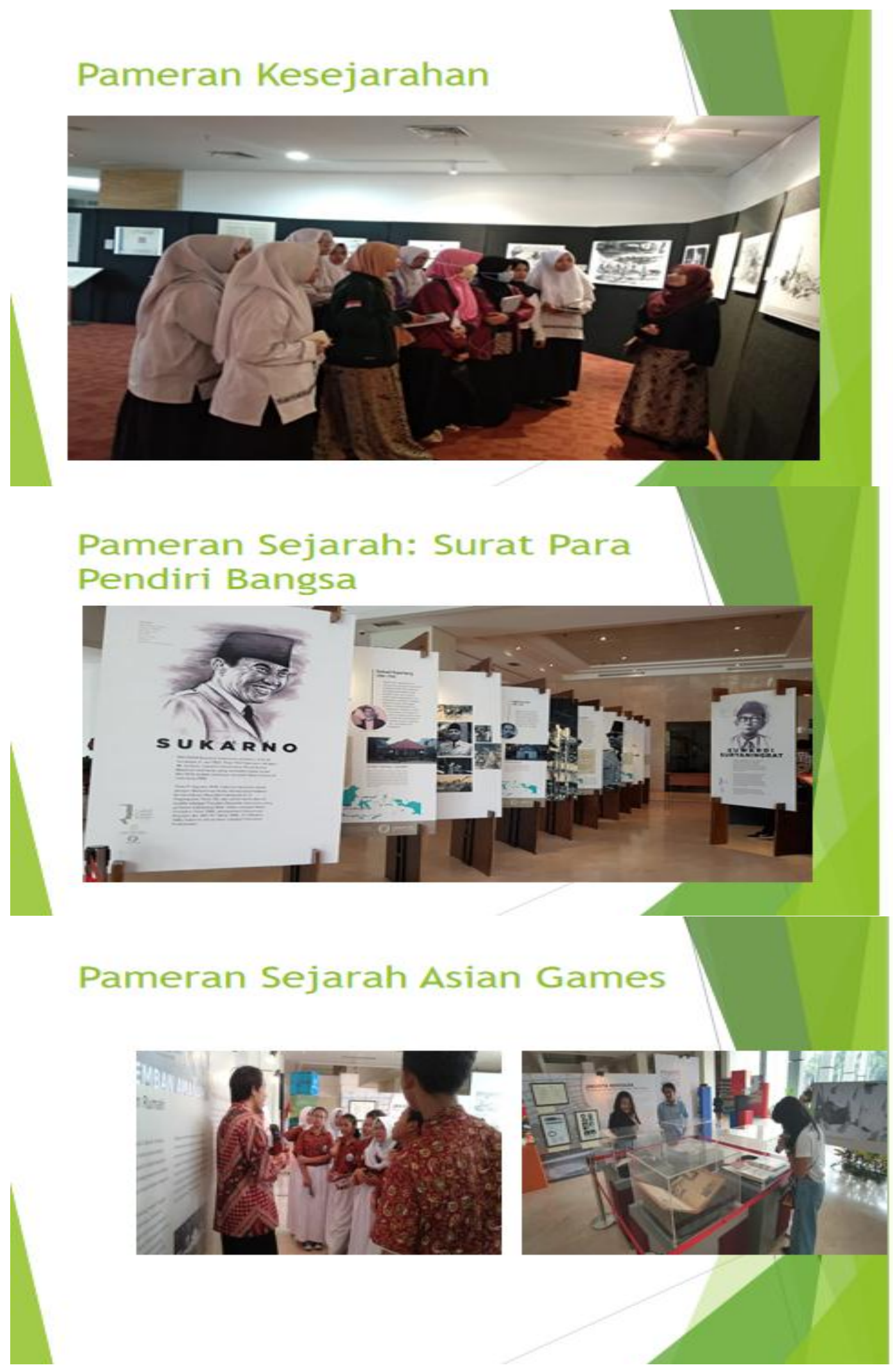

89 | Seminar Nasional Sejarah ke 4 Jurusan Pendidikan Sejarah Universitas Negeri Padang 


\section{Mengenalkan sejarah melalui film inspiratif}

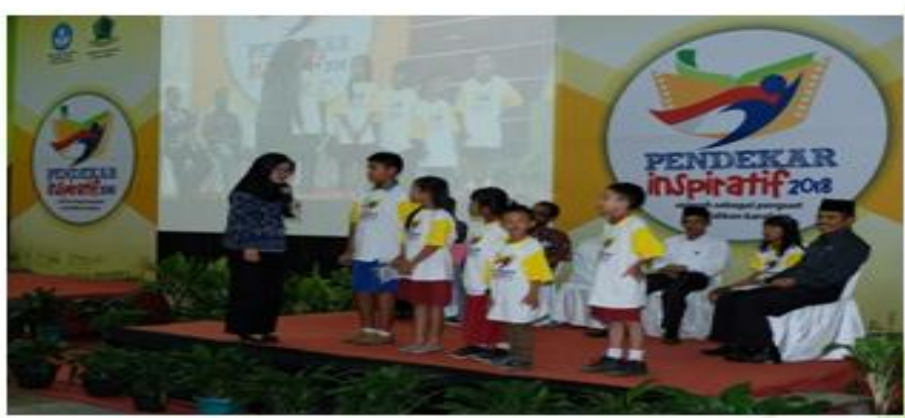

Kemah Budaya Nasional
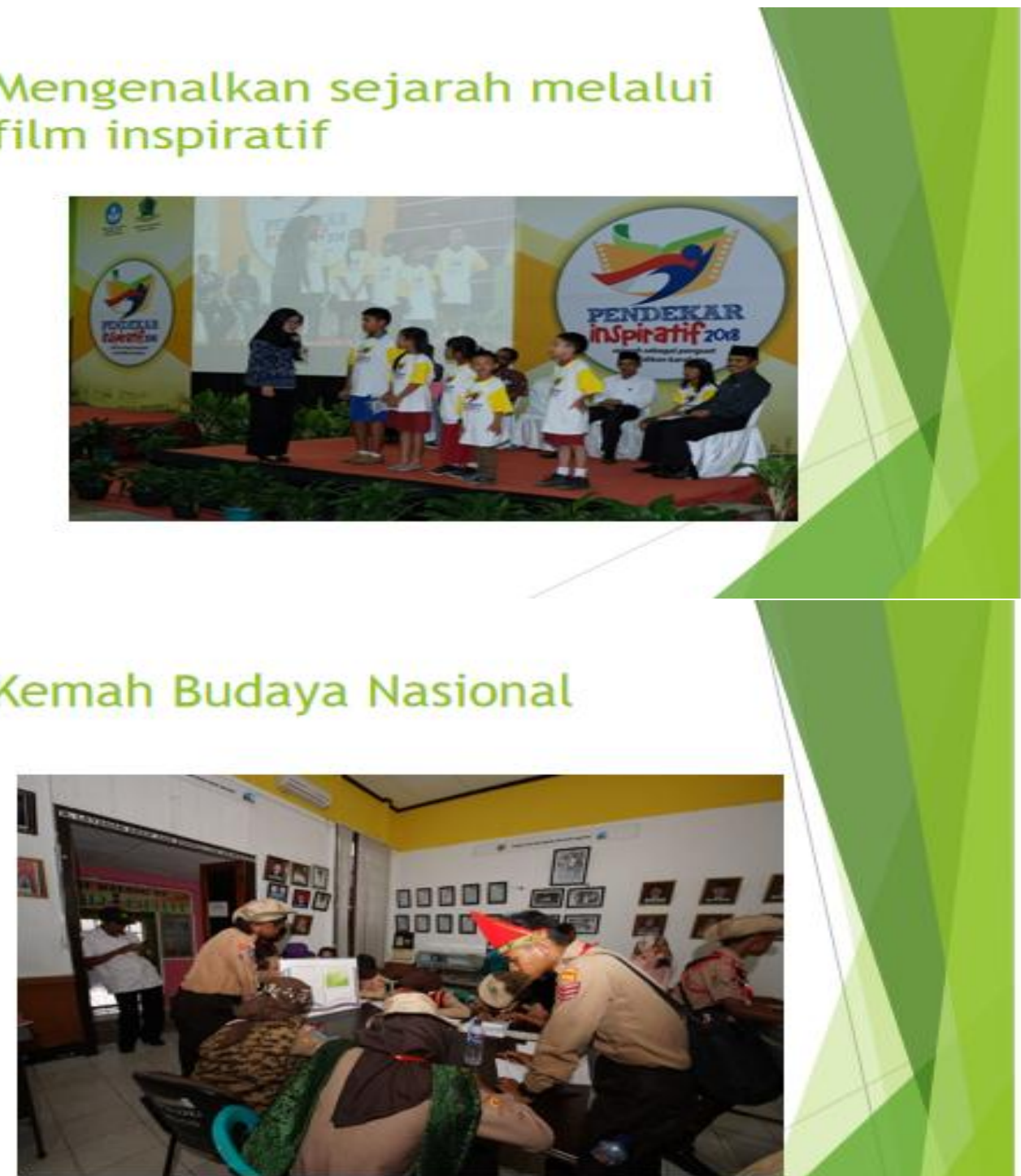


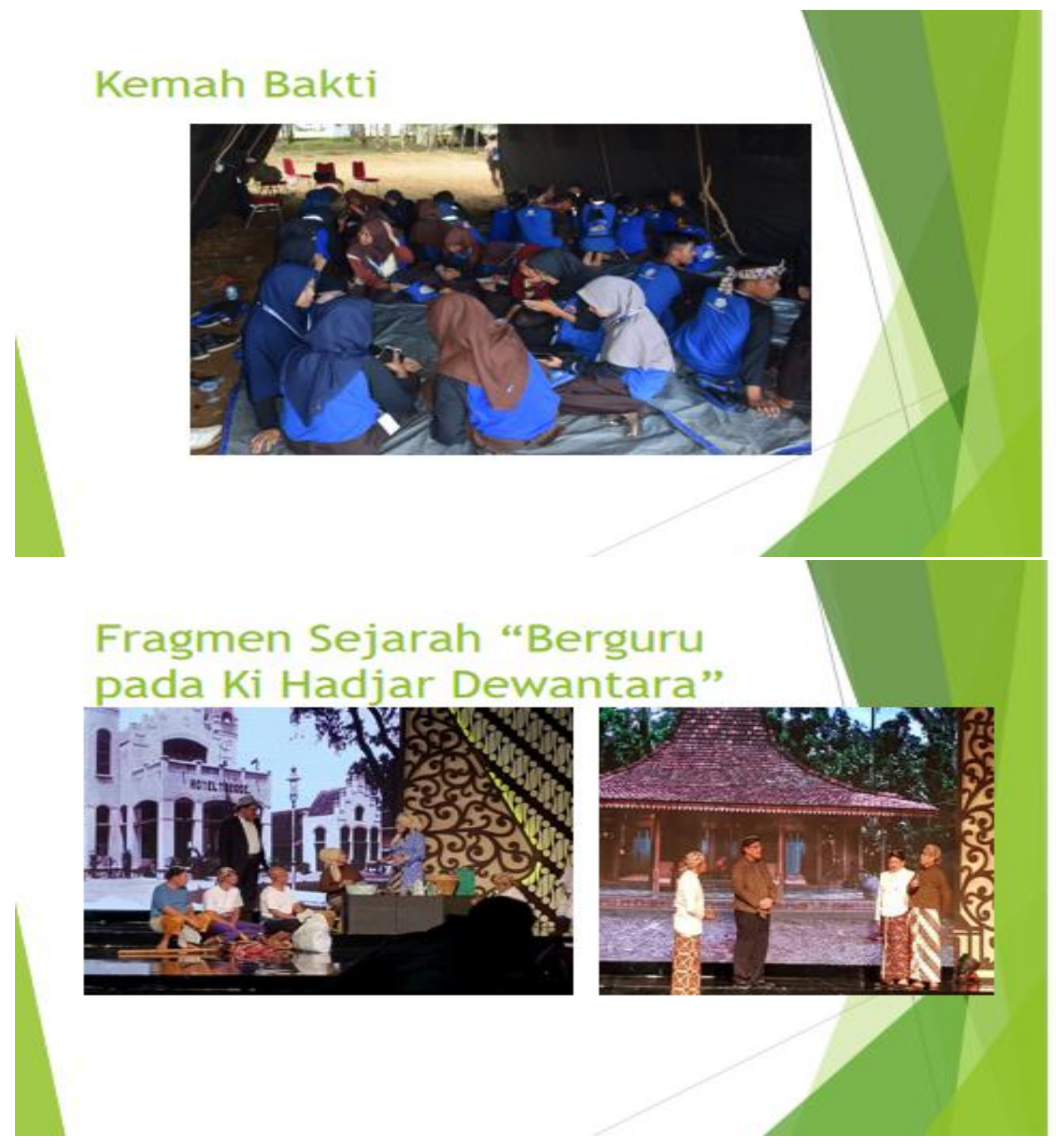




\section{Kami hadir di sini...}

- Direktorat Sejarah

https://kebudayaan. kemdikbud.go.id/ditsejarah/

- Database Kesejarahan

http://seiarah.dapobud. kemdikbud.go.id

- Pustaka Kebudayaan

http://pustaka.kebudayaan.kemdikbud.go.id/sejarah

- E-Journal Abad Dit. Sejarah

- hittps://jurnalabad.kemdikbud.go.id

\section{Kami hadir di sini...}

- Facebook https://www.facebook.com/direktoratsejarah.kemendi kbud.1

- Twitter Direktorat Sejarah https://twitter.com/sejarahdikbud

- Sejarah_Kita

https://www.youtube.com/watch?v=9KL5n98T2qk

- Sejarah_Kita_ https://www.instagram.com/sejarah kita

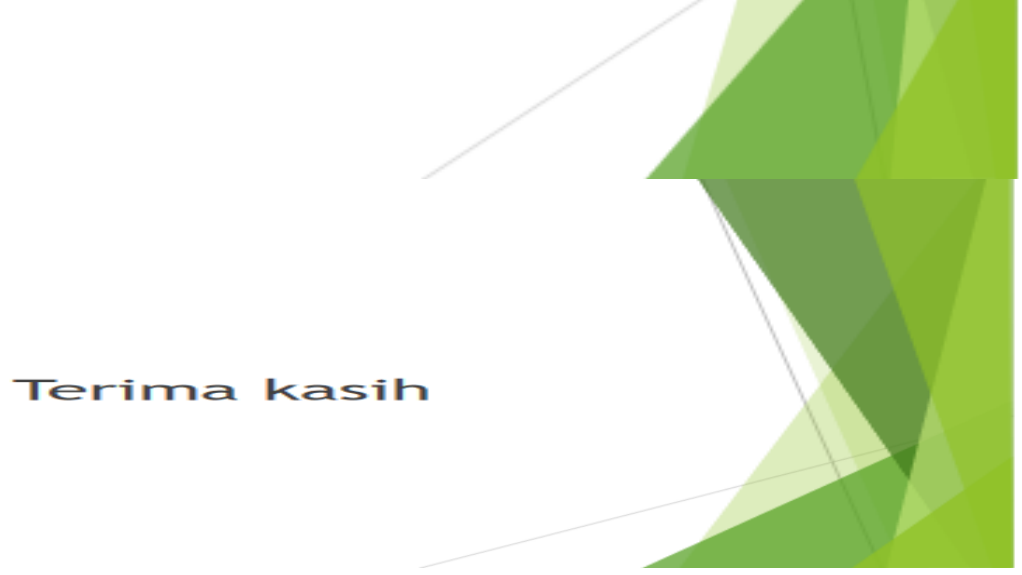

92 | Seminar Nasional Sejarah ke 4 Jurusan Pendidikan Sejarah Universitas Negeri Padang 